University of Nebraska - Lincoln

DigitalCommons@University of Nebraska - Lincoln

Anthropology Faculty Publications

Anthropology, Department of

October 1973

Crowding among Hunter-Gatherers: The !Kung Bushmen

Patricia Draper

University of Nebraska, Lincoln, pdraper1@unl.edu

Follow this and additional works at: https://digitalcommons.unl.edu/anthropologyfacpub

Part of the Anthropology Commons

Draper, Patricia, "Crowding among Hunter-Gatherers: The !Kung Bushmen" (1973). Anthropology Faculty Publications. 10.

https://digitalcommons.unl.edu/anthropologyfacpub/10

This Article is brought to you for free and open access by the Anthropology, Department of at DigitalCommons@University of Nebraska - Lincoln. It has been accepted for inclusion in Anthropology Faculty Publications by an authorized administrator of DigitalCommons@University of Nebraska - Lincoln. 
Published in Science, New Series, Vol. 182, No. 4109, (October 19, 1973), pp. 301-303.

Copyright (C) 1973 American Association for the Advancement of Science. Used by permission.

Submitted March 27, 1973.

\title{
Crowding among Hunter-Gatherers: The !Kung Bushmen
}

\author{
Patricia Draper \\ Department of Anthropology, \\ University of New Mexico, \\ Albuquerque, NM 87106
}

\begin{abstract}
Highly crowded living conditions exist among the !Kung Bushmen, hunter-gatherers who live on the edges of the Kalahari Desert in Botswana and South-West Africa. The !Kung appear to be crowded by choice, and biological indicators of stress are absent. Data indicate that residential crowding alone does not produce symptoms of pathological stress.
\end{abstract}

Recent studies of crowding among nonhuman primates and other mammals suggest that various biological and social pathologies are associated with abnormally increased population density (1). The effects of density, however, vary among different species; while speculations are increasing in the popular literature about the deleterious effects of crowding on humans (2), in fact, the evidence for the effect of crowding is equivocal. An article by Galle et al. (3) reviewed the problem of interpreting the possible significance to man of density effects observed in other mammals and suggest refinements of the concept of density with reference to human (particularly urban) populations. The authors recommended specifying sepa- rate components of density (the number of persons per room, the number of rooms per housing unit, the number of housing units per structure, the number of residential structures per acre) instead of relying on an overall measure of population density in terms of numbers of people per unit area. The authors suggested that for certain pathologies the most important components of density are those related to "interpersonal press," such as the number of persons per room and number of housing units per structure. Most investigators agree that the overcrowding in certain areas of cities and among particular ethnic groups contributes to poor public health, although the parameters of density and their individual and multiple re- lations to pathology are only beginning to be studied (4).

In this report I will present data which show that intense interpersonal press exists among a people whose population density [approximately one person per 10 square miles (5) ] is among the lowest in the world - the !Kung Bushmen of Ngamiland, Botswana and northeastern Namibia (South West Africa). However, in their camp settlements these people experience extreme crowding without any conceivable economic or ecological constraint which might produce it. The !Kung are free of biological indicators thought to be indicative of high stress. For example, blood pressures are low and do not rise with age, and serum cholesterol levels are among the lowest in the 
Table 1. Occupation density of four !Kung camps.

\begin{tabular}{|c|c|c|c|c|}
\hline Date & Place & $\begin{array}{r}\text { People in } \\
\text { camp } \\
(\text { No. })\end{array}$ & $\begin{array}{r}\text { Camp area } \\
\text { (square } \\
\text { feet) }\end{array}$ & $\begin{array}{r}\text { Square } \\
\text { feet per } \\
\text { person }\end{array}$ \\
\hline July 1969 & $\neq \mathrm{To} / /$ gana & 17 & 698 & 42 \\
\hline August 1969 & $\begin{array}{c}\neq \mathrm{To} / / \text { gana } \\
\text { Fence }\end{array}$ & 28 & 4419 & 158 \\
\hline September 1969 & $\begin{array}{l}\neq \mathrm{To} / / \text { gana } \\
\text { Tsi N! }\end{array}$ & 40 & 7079 & 176 \\
\hline \multirow[t]{2}{*}{ October 1969} & $\begin{array}{c}\neq \mathrm{To} / / \text { gana } \\
\text { Fence }\end{array}$ & 24 & 8343 & 348 \\
\hline & & & & Average 181 \\
\hline
\end{tabular}

world (16). The !Kung are unfazed by the press and are able to maintain a multisensory, diffuse contact with each other that is supportive rather than stressful.

The !Kung are well described in the anthropological literature, notably by members of the Marshall family (7) and by members of the Harvard Kalahari Project (8). The !Kung are of interest since their way of life preserves an adaptation thought to be characteristic of most of man's evolutionary history. Students of these and other contemporary hunter-gatherers hope that understanding the social organization and economy of living hunters and gatherers can lead to an understanding of our own evolutionary heritage.

The !Kung group which was studied is a population of about 150 people who, in 1968 and 1969, were living on the border between Botswana and South-West Africa, approximately 100 miles north of Ghanzi, Botswana. They lived wholly by hunting and gathering and were not associated with or dependent upon Bantu pastoralists. They lived in kin-based groups averaging 30 to 40 people. The group composition was not stable over time, nor territorial, nor organized by any rigid kinship criterion. Instead, group size and mobility were determined by availability of water, game, and bush food and the wishes of individuals to visit other groups (9).

The !Kung settlement pattern ensures that coresidents are maximally close together. The area of village occupation is small, compact, and densely settled. Table 1 gives information on the size and number of inhabitants of four !Kung camps. The average density of occupation of these camps (based on diagrams made over a 4-month period) was 188 square feet per person. This compares with 350 square feet per person which was set as the desirable standard by the American Public Health Association (10). Not only are people closely packed in (arbitrarily) limited space, but the organization of the interior space in each settlement increases the exposure of each individual to another. !Kung women build small grass huts, one per family, and locate them at the outer edges of a circular village space. The inner area is carefully denuded of grass, bushes, saplings, or anything which might provide shade or privacy or screen one part of the village from another. The huts themselves do not break up the inner space or create micro-neighborhoods. People do not live in the huts or go into them for rest or privacy; rather the huts are used for dry storage of food, skins, and tools. Each hut, with its own hearth, is a marker signifying the residence of one nuclear family. Typically huts are so close that people sitting at different hearths can hand items back and forth without getting up. Often people sitting around various fires will carry on long discussions without raising their voices above normal conversational levels.

In addition to high per person density per unit area, and the absence of rooms, walls, or other architectural features which limit access by one person to another, !Kung camps are well staffed during the day. One might expect, for example, that camps would be deserted during the day, with people dispersed into the bush in search of game, bush food, and water. In fact, the organization of work and leisure is such that during an average day about 65 percent of the camp residents are at home in the settlement. Children under age 14, adolescents, and old people contribute little or nothing to the work of food collecting. The day-today life is not arduous, despite the inhospitable environment and the simple technology with which the !Kung are equipped. Able-bodied adults hunt and gather on an average of about 3 days per week. The !Kung are not unique among hunter-gatherers in their modest work effort; recent studies by students of living hunter-gatherers are correcting an earlier widespread notion of privation among hunter-gatherers (11).

The !Kung live in sufficient abundance that they do not require work from children, and the nature of adult work is such that children cannot easily be incorporated into it. The scarcity of water is the chief limiting factor. Much of the year there is no standing water, and, for children to work with their parents, additional water would have to be brought from camp for them. Men and women both prefer to leave children at camp in order to travel lighter and work more efficiently. Children are well supervised by the remaining adults at camp-the elderly or the men and women who are not working for the day.

In the matter of adult supervision of children, the !Kung are unlike crowded urban populations, where parents are unable to control the movements, associations, and activities of their children. Perhaps the single most striking feature of !Kung childhood is the extraordinarily close association between children and adults. Children living in these small band encampments have virtually no place where they can go, such as a public gathering place, or a field where animals are pastured or crops are tended. There is only the camp space; beyond that stretches the Kalahari bush, which from a child's vantage point is vast, undifferentiated, and unsocialized. Children spend most of their time within the circle of huts, although both age and sex influence the extent to which children use the bush near the campsite.

Field research was focused on child life and behavior, but the small size of !Kung living groups meant that most aspects of life and individuals of all ages could be readily observed. The data gathered consisted mainly of timed, randomized, and written observations of the natural behavior of children. Data from spot observations of each subject child included such information as date, time of day, child's identification number, his whereabouts in space (inside or outside the circle of huts), and the number, names, 
and identification numbers of other people (if any) in his immediate group of interactants. Also noted in the spot observation were such particulars as whether or not other people were nearby (but not in his immediate group of interactants), where his mother and father were at that moment in time, and whether the child was in physical contact with another person at the moment of the spot observation. The observations were carried out at different times during the daylight hours in order to sample evenly throughout the day of each child. As a research tool, the spot observation has many advantages: information can be gathered quickly, and observations can be made repeatedly of all the children of a group for many days in succession.

In a series of 165 systematically collected, randomized spot observations of 30 children living in the bush, girls (14 years and under) showed an average score of .77 on being inside the circle of huts. (In this usage, a "score" for each child is the proportion of spot observations during which the given behavior was observed.) Boys of the same age range had an average score of .50 on being inside the circle. One or more adults (for reasons already stated) was always present with the children within the village circle. At other times, children played in the bush adjacent to the camp circle but generally were still within eye or ear contact with adults in camp. As might be expected, older children used the near bush more frequently than young children.

!Kung children spent a minor portion of their time in children-only play groups; typically they were found in informal interactive clusters which included one or more adults. Girls had an average score of .77 on being in faceto-face clusters which included one or more adults. The average score for boys on this measure was .66 .

The human press in !Kung camps is clearly extreme. The campsites themselves are tightly packed, and the absence of physical barriers combined with the circular arrangement of in-ward-facing huts means, effectively, that approximately 30 people are living in a single room. The !Kung apparently like to be close together, even touching. As people sit in camp, resting, talking, and doing chores, they prefer to gather in knots or clumps, leaning against each other, their arms brushing, their crossed legs overlapping. Physical contact reaches its highest expression among children. Girls showed an average of .57 on being in physical contact with at least one other person. The average score for boys was .35 .

Refinements of the concept of density may improve our grasp of the relationship between space and the quality of human life. In the !Kung example their are several conditions which may facilitate accommodation to close interpersonal press in daily life. Individuals or families have the culturally acceptable option of moving from one camp to another. Band fission seems to be a time-honored technique which bandlevel peoples employ to resolve conflict. !Kung bands are in a more or less continuous state of flux, largely in response to changes in food and water supplies, although personal conflict also motivates changes in group membership. In contrast, individuals living in modern urban ghettos probably lack this mobility option. Moving in itself may be expensive, work may not be available elsewhere, the social networks linking friends and relatives who can lend economic support are likely to be severely truncated in comparison with those which link individuals in a small, kin-based society such as the !Kung.

A !Kung family can move and thereby escape social tensions and effect a change of faces. However, the new camp will be very similar in settlement pattern and in density of occupation, and it will be staffed, not with strangers with whom a person can make a new start, but with relatives and acquaintances who are known to the individual through years of intermittent coresidence.

Another condition which may facilitate accommodation to close interpersonal press may derive from the fact that the camp settlement, although densely packed, is well separated from others like it. In the area in which this study was carried out, groups with an average size of 30 to 40 people were typically separated by 15 or more miles. This uninhabited area minimized both visiting and chance encounter with strangers. It is possible that stranger density is an important component of modern urban stress. !Kung rarely encounter strangers, and when such meetings do occur, the parties can readily establish a basis for cooperation by establishing a genealogical connection.

Whatever may be the ameliorating conditions, it is clear that the !Kung are crowded, yet the absence of presumably stress-related diseases suggests that residential crowding is not necessarily related to social pathology.

\section{References and Notes}

1. J. Calhoun. Sci. Amer. 206, 139 (Feb. 1962); V. Wynne-Edwards, Animal Dispersion in Relation to Social Behavior (Oliver \& Boyd, London, 1962); R. Snyder, in Progress in Physiological Psychology, E. Stellar and J. Sprague, Eds. (Academic Press, New York, 1968), pp. 119-160.

2. R. Ardrey, African Genesis (Atheneum, New York, 1961); The Territorial Imperative (Atheneum, New York, 1966); D. Morris, The Naked Ape (McGraw-Hill, New York, 1967).

3. O. R. Galle, W. R. Gove, J. M. McPherson, Science 176, 23 (1972).

4. R. E. Mitchell, Amer. Soc. Rev. 36, 18 (1971).

5. Approximate conversion factors are: 1 square mile $=2.590$ square kilometers; 1 mile $=$ 1.609 kilometers; 1 square foot $=0.093$ square meter.

6. A. S. Truswell and J. D. L. Hansen, S. Afr. Med. J . 42, 1338 (1968); Lancet 1968-II, 684 (1968); B. M. Kennelly et al., S . Afr. Med. $J$. , in press.

7. J. Marshall, thesis, Harvard University (1957); Natur. Hist. 67, 291 (1958); ibid., p. 376; L. Marshall, Africa 29, 335 (1959); ibid. 27, 1 (1957); ibid. 30, 325 (1960); ibid. 31, 231 (1961); ibid. 32, 221 (1962); E. M. Thomas, The Harmless People (Knopf, New York, 1959).

8. R. B. Lee, thesis, University of California (1965); in Man the Hunter, R. B. Lee and I. DeVore, Eds. (Aldine, Chicago, 1968), pp. 30-48; Natur. Hist. 28, 14 (1969); ibid., p. 60; in Ecological Essays, D. Damas, Ed. (National Museum of Canada, Ottawa, 1969), pp. 73-94; H. Harpending and J. Yellen, World Archaeology, in press; P. Draper Harpending, thesis, Harvard University (1972).

9. R. B. Lee, in preparation.

10. American Public Health Association, Committee on Hygiene of Housing, Planning the Home for Occupancy (Public Administration Service, Chicago, 1950).

11. R. B Lee, in Man the Hunter, R. B. Lee and I. DeVore, Eds. (Aldine, Chicago, 1968); M. Sahlins, in ibid., pp. 85-89; J . Woodburn. in ibid., pp. 49-55.

12. This work was supported by NIH grant MH 13611 to Irven DeVore and Richard B. Lee. Fieldwork was done in 1968 and 1969 for 22 months. 